\title{
De invloed van het EU-recht op het Nederlandse consumentenkooprecht
}

\author{
Mr. S. van Beek en prof. mr. H.N. Scbelbaas*
}

\begin{abstract}
1 Inleiding
Ben ik mijn broeders hoeder? De Europese Unie is dat al enige decennia voor de consument. Dat is destijds ingegeven door de gedachte dat een groot verschil in niveau van consumentenbescherming in Europa bestond, hetgeen grensoverschrijdende consumententransacties verhinderde en de werking van de interne markt verstoorde. Daarnaast was relevant dat de juridische positie van de consument vaak ondergeschikt en zwak is, mede vanwege zijn informatieachterstand en het gebrek aan onderhandelingspositie jegens zijn professionele wederpartij. Beide factoren hebben ervoor gezorgd dat de Europese Unie sinds de jaren tachtig van de vorige eeuw een groot aantal richtlijnen heeft uitgevaardigd om de juridische positie van de consument in algemene zin te verstevigen en Europese regelgeving nader tot elkaar te brengen. Meestal werd ernaar gestreefd om de rechten van consumenten in ieder geval op een gemeenschappelijk minimumniveau ${ }^{1}$ te brengen, soms werd beoogd om een volledig geharmoniseerd ${ }^{2}$ consumentenregime in Europa te creëren.
\end{abstract}

In het kader van dit themanummer over gamechangers in het Europees privaatrecht, stellen wij ons de vraag tot welke veranderingen deze Europese consumentenbeweging in het Nederlandse recht heeft geleid. Wij richten ons hierbij louter op de consumentenkoop, ${ }^{3}$ omdat dit één van de terreinen van het consumentenrecht is waar de $\mathrm{EU}$ in het bijzonder actief is geweest en het een veel voorkomende overeenkomst is. $\mathrm{W}_{\mathrm{ij}}$ doen dat met een overkoepelende blik en gaan, gezien het bestek van deze bijdrage en de opzet van dit themanummer, niet uitputtend in op de details van de kooptitel, maar richten ons op een aantal algemene ontwikkelingen die een tendens weergeven.

Uit het brede scala van onderwerpen op het gebied van de consumentenkoop, hebben wij drie onderwerpen gelicht die

\footnotetext{
Mr. S. van Beek is als wetenschappelijk docent verbonden aan de afdeling Burgerlijk Recht van de Erasmus School of Law, Erasmus Universiteit Rotterdam. Prof. mr. H.N. Schelhaas is hoogleraar privaatrecht aan de Erasmus Universiteit Rotterdam en redacteur van dit blad.

1. Bijv. Richtlijn 1999/44/EG betreffende bepaalde aspecten van de verkoop van en de garanties voor consumptiegoederen, PbEG 1999, L 171/12.

2. Bijv. Richtlijn 2011/83/EU betreffende consumentenrechten, PbEU 2011, L 304/64.

3. Oftewel, de koopovereenkomst, waarbij een consument zaken koopt van een commerciële professioneel handelende wederpartij.
}

wat ons betreft goede voorbeelden vormen van de invloed van het EU-recht op het Nederlandse recht: (i) de consumentenkoop op afstand, waar het Nederlandse recht in het geheel geen regeling voor had, (ii) de non-conformiteitsregels en het daarbij horende (getrapte) stelsel van remedies, en (iii) de klachtplicht bij consumentenkoop. Deze keuze leidt ertoe dat een aantal wat ons betreft minder wezenlijke onderwerpen buiten beschouwing blijven, zoals de regeling over garanties, ${ }^{4}$ de verzuimregeling bij de verplichting tot eigendomsoverdracht (art. 7:19a BW) en de uitbreiding van de reikwijdte van de consumentenkooptitel naar aannemingsovereenkomsten (art. 7:5 lid $4 \mathrm{BW}$ ). ${ }^{5}$ Het novum van de ambtshalve toetsing van het consumentenkooprecht ${ }^{6}$ laten we om een andere reden buiten beschouwing: dit belangrijke onderwerp wordt elders in dit themanummer al beroerd.?

Nadat wij eerst kort hebben stilgestaan bij de achtergrond van het Nederlandse kooprecht en de belangrijkste Europese richtlijnen op dit gebied, bezien wij wat de invloed van het Unierecht is geweest op de regeling koop op afstand (par. 3), de regeling inzake de non-conformiteit en de daarbij beschikbare remedies (par. 4) en de klachtplicht bij consumentenkoop (par. 5). Vervolgens reflecteren wij in paragraaf 6 op de ontwikkelingen die nog te verwachten zijn, waarna wij enige conclusies trekken (par. 7).

4. Art. 7:6a BW schrijft een aantal technische en formele punten voor waar een garantie aan moet voldoen. De wat ons betreft belangrijkste regel over garanties volgt echter uit een bestaande bepaling: de vaak voorkomende garantie die in wezen de rechten van de consument beperkt, is krachtens art. 7:6 jo. art 3:40 BW vernietigbaar.

5. Zie nader over andere wijzigingen: J.W.A. Biemans, De invloed van de richtlijnen consumentenkoop en consumentenrechten op de regeling van consumentenkoop in Titel 7.1 BW, in: A.S. Hartkamp e.a. (red.), De invloed van het Europese recht op het Nederlandse Privaatrecht, 2e druk, Deventer: Wolters Kluwer 2014, p. 371 e.v. Ook de samenloop van de consumentenkoopregeling met de productenaansprakelijkheidsregeling (art. 7:24 jo. art. 6:185 e.v BW.), laten wij buiten beschouwing, omdat zulks niet zozeer een uitvloeisel is van de consumentenkoopregeling, maar veeleer van de Europese richtlijn productaansprakelijkheid. Een goed begrip van deze samenloop zou een uitgebreide behandeling van de delictuele productaansprakelijkheidsregeling vergen en dat gaat het bestek van deze bijdrage te buiten. Wij merken wel op dat deze samenloop ervoor zorgt dat de consument bij schade als gevolg van een gebrekkig en gevaarlijk product veelal niet de verkoper maar de producent moet aanspreken: zie art. 7:24 lid 2 BW.

6. HvJ EU 4 juni 2015, C-497/13, ECLI:EU:C:2015:357, NJ 2016/148 (Faber/Autobedriff Hazet Ochten BV).

7. Zie nader hierover in dit nummer D.F.H. Stein, Richtlijnen en privaatrecht. 


\section{De achtergrond van het Nederlandse en Europese recht inzake de consumentenkoop}

Het Nederlandse BW kende al een wettelijke regeling voor de consumentenkoop voordat de EU de eerste richtlijn op dit terrein uitvaardigde. Het voorontwerp voor het Nederlandse kooprecht stamt al uit 1978 en was in aanzienlijke mate gebaseerd op de voorloper van het Weens Koopverdrag8, het LUVI (Loi uniforme sur la vente internationale des objets). Met de inwerkingtreding van het BW in 1992 werd ook de nieuwe regeling voor de koop ingevoerd, waar de consumentenkoop deel van uitmaakte. Sinds 1992 is de Nederlandse koop-titel een aantal malen gewijzigd, vooral omdat Europese ontwikkelingen daartoe noopten.

In de eerste plaats heeft de in 1999 uitgevaardigde Europese richtlijn consumentenkoop de Nederlandse regeling beïnloed. ${ }^{9}$ Deze richtlijn gaat uit van minimumharmonisatie, hetgeen betekent dat een basisniveau van consumentenbescherming in alle lidstaten moet zijn gewaarborgd, maar dat lidstaten ervoor kunnen kiezen om een voor consumenten (nog) gunstiger regime te implementeren.

In de tweede plaats heeft ook de Richtlijn consumentenrechten uit $2011^{10}$ het Nederlandse kooprecht beïnvloed, maar minder dan de EU aanvankelijk had bedacht. Het oorspronkelijke plan was namelijk om een volledig geharmoniseerd Europees consumentenkooprecht te realiseren, waarbij de Richtlijn consumentenrechten de eerdere Richtlijn consumentenkoop zou vervangen en over de hele linie zou uitgaan van volledige harmonisatie. ${ }^{11}$ Omdat de eerdere richtlijn slechts minimumharmonisatie propageerde en een aantal lidstaten een verdergaand consumentenbeschermingsregime hadden ingevoerd, zou dat betekenen dat deze landen hun regeling moesten bijstellen naar een lagere beschermingsgraad voor consumenten. Dit leidde tot verzet, met als gevolg dat de Richtlijn consumentenkoop minder vooruitstrevend is vormgegeven dan aanvankelijk was voorzien: de oorspronkelijke Richtlijn consumentenkoop is niet aangetast. Wat die richtlijn betreft geldt dus nog minimumharmonisatie. Alleen ten aanzien van nieuwe rechten en verplichtingen die uit de recentere Richtlijn consumentenrechten voortvloeien is sprake van volledige

8. Het materiële toepassingsgebied van het Weens Koopverdrag is de internationale koop van roerende zaken tussen professionele partijen.

9. Richtlijn 2019/771/EU betreffende bepaalde aspecten van de verkoop van en de garanties voor consumptiegoederen, PbEG L 171/12. Dit heeft in 2003 tot enige wijzigingen geleid: Wet van 6 maart 2003, Stb. 2003, 110, inwerkingtreding 1 mei 2003. Voor een overzicht van enige wijzigingen: N. Frenk, Herziening van de regeling consumentenkoop, AA 2003/12, p. 953-959; J.M. Smits, De richtlijn consumentenkoop en het Nederlandse recht, in: J.M. Smits (red.), De richtlijn consumentenkoop in perspectief, Den Haag: BJu 2003, p. 1-27; J.W.A. Biemans, De invloed van de richtlijnen consumentenkoop en consumentenrechten op de regeling van consumentenkoop in Titel 7.1 BW, in: A.S. Hartkamp e.a. (red.), De invloed van het Europese recht op het Nederlandse Privaatrecht, 2e druk: Deventer: Wolters Kluwer 2014, p. 371 e.v.

10. Richtlijn 2011/83/EU bettreffende consumentenrechten, PbEU L 304/64.

11. Zie nader M.B.M. Loos, Consumentenkoop (Mon. BW nr. B65b), Deventer: Kluwer 2014, nr. 2. harmonisatie. ${ }^{12}$ Vanaf 2022 komt hier echter verandering in, als de nieuwe Richtlijn consumentenkoop moet zijn geïmplementeerd, die de richtlijn uit 1999 vervangt en wel (grotendeels) $^{13}$ uitgaat van volledige harmonisatie. ${ }^{14}$

Daarnaast hebben Europese ontwikkelingen gezorgd voor de intrede van een geheel nieuwe regeling voor overeenkomsten op afstand in het BW. ${ }^{15}$ Eerst zag de Richtlijn koop op afstand het licht, die leidde tot een nieuwe titel in Boek 7 van het BW. Het bereik van de regeling werd door de Richtlijn consumentenrechten verbreed naar élke overeenkomst op afstand en is daarom verplaatst naar Boek 6 van het BW (afdeling 6.5.2B).

Het feit dat de koop-regeling in het Nederlandse BW voor een deel van Nederlandse origine is en voor een deel bestaat uit geïmplementeerd Unierecht, leidt tot een pluriforme regeling, waarbij wat betreft het 'nationale' deel de Hoge Raad de hoogste rechter is, en voor de regels van Europese origine ten aanzien van de consumentenkoop het Europese Hof van Justitie (HvJ EU) de hoogste bevoegde instantie is. Het HvJ EU heeft inmiddels een groot aantal belangwekkende arresten gewezen dat de Nederlandse koop-titel nader inkleurt. Wij stippen in deze bijdrage enkel de belangrijkste uitspraken kort aan.

\section{Koop op afstand; de informatieplicht en het herroepingsrecht}

\subsection{De Europeesrechtelijke aanleiding voor een regeling inzake koop op afstand}

De eerste gamechanger die het Unierecht in het Nederlandse recht teweeg heeft gebracht, is een regeling die de koop op afstand reguleert. Vanwege de opkomst van nieuwe technologieën die steeds vaker werden gebruikt bij de (grensoverschrijdende) verkoop op afstand en de daarmee in verband staande onzekerheid die deze technologische explosie vanuit juridisch oogpunt met zich bracht, heeft de Europese Unie op 20 mei 1997 de hiervoor al kort vermelde Richtlijn koop op afstand ${ }^{16}$

12. Krachtens art. 33 Richtlijn consumentenrechten blijft de Richtlijn consumentenkoop ongewijzigd, met uitzondering van een nieuwe verslagleggingsverplichting. Uit art. 4 volgt de volledige harmonisatie.

13. Zie M.B.M. Loos, Herziening regelingen kooprecht en digitale inhoud aanstaande, TvC 2019/3 voor de uitzonderingen op het uitgangspunt van volledige harmonisatie.

14. Richtlijn 2019/771/EU betreffende bepaalde aspecten van overeenkomsten voor de verkoop van goederen, tot wijziging van Verordening (EU) 2017/2394 en Richtlijn 2009/22/EG, en tot intrekking van Richtlijn 1999/44/EG, PbEU 2019, L 136/28. Art. 4 geeft weer dat het gaat om volledige harmonisatie. Op dezelfde datum is Richtlijn (EU) 2019/770 betreffende bepaalde aspecten van overeenkomsten voor de levering van digitale inhoud en digitale diensten, PbEU 2019, L 136/1 verschenen, die ook in 2022 moet zijn geimplementeerd.

15. Richtlijn 97/7/EG betreffende de bescherming van de consument bij op afstand gesloten overeenkomsten, PbEG 1997, L 144/19. Deze werd nog voorafgegaan door Richtlijn 85/577/EEG betreffende de bescherming van de consument bij buiten verkoopruimten gesloten overeenkomsten (colportage).

16. Richtlijn $97 / 7 /$ EG betreffende de bescherming van de consument bij op afstand gesloten overeenkomsten, PbEG 1997, L 144/19. 
aangenomen. ${ }^{17}$ Het doel van de richtlijn was de wettelijke bepalingen van de lidstaten inzake op afstand gesloten overeenkomsten nader tot elkaar te brengen. ${ }^{18}$ Mede vanwege de minimumharmonisatie die ten grondslag lag aan deze richtlijn, bleven de regelingen in Europa inzake de koop op afstand echter uiteenlopen. Mede om deze reden, gecombineerd met het besef dat internationale transacties op het internet van toenemend belang waren, ${ }^{19}$ is in 2014 met de Richtlijn consumentenrechten ${ }^{20}$ een nieuwe regeling in werking getreden. ${ }^{21}$ Het doel van deze richtlijn is bij te dragen aan de goede werking van de interne markt door het vertrouwen van de consument in de interne markt te versterken en de terughoudendheid van het bedrijfsleven inzake grensoverschrijdende handel te verminderen. ${ }^{22}$ De richtlijn is breder dan de richtlijn koop op afstand: zij behelst meer onderwerpen en heeft bovendien de reikwijdte verbreed naar alle overeenkomsten op afstand.

\subsection{Veranderingen in het Nederlandse privaatrecht}

Aangezien in Nederland nog geen specifieke wet inzake op afstand gesloten overeenkomsten bestond, leidde de inwerkingtreding van de Richtlijn koop op afstand tot een aanzienlijke verandering in de rechtspositie van de Nederlandse consument bij op afstand ${ }^{23}$ gesloten overeenkomsten. Met de implementatie van deze richtlijn werden twee belangrijke nieuwe rechtsfiguren in het Nederlandse privaatrecht geïntroduceerd, te weten de informatieplicht van de verkoper en het herroepingsrecht van de consument bij op afstand gesloten overeenkomsten. Hoewel de Richtlijn consumentenrechten ten opzichte van de Richtlijn koop op afstand geen radicale vernieuwingen met zich bracht, werden de twee centrale onderwerpen van deze laatstgenoemde richtlijn wel aanzienlijk verruimd.

De eerste grote verandering, de precontractuele informatieplicht van de verkoper, houdt onder andere in dat de verkoper, voordat de consument aan de overeenkomst gebonden is, op duidelijke en begrijpelijke wijze over twintig punten informa-

17. Zie o.m. COM(91)11 def en Kamerstukken II 1999/00, 26861, 3.

18. Zie art. 1 Richtlijn koop op afstand.

19. Zie de overwegingen 5 en 6 bij de Richtlijn consumentenrechten.

20. Richtlijn 2011/83/EU van 25 oktober 2011 betreffende consumentenrechten, tot wijziging van Richtlijn 93/13/EEG en van Richtlijn 1999/44/EG en tot intrekking van Richtlijn 85/577/EEG en van Richtlijn 97/7/EG, PbEU 2011, L 304/64.

21. Zie art. 4 Richtlijn consumentenrechten. Zie verder over volledige of maximumharmonisatie V. Mak, De grenzen van maximumharmonisatie in het Europese consumentenrecht, NTBR 2011/77.

22. Zie art. 1, in samenhang met de overwegingen 5 en 6, van de Richtlijn consumentenrechten.

23. Dat is (zie art. 6:230g BW) de overeenkomst waarbij in het kader van een georganiseerd systeem voor de verkoop of dienstverlening op afstand zonder gelijktijdige persoonlijke aanwezigheid van handelaar en consument en waarbij, tot en met het moment van het sluiten van de overeenkomst, uitsluitend gebruik wordt gemaakt van een of meer middelen voor communicatie op afstand. tie dient te verstrekken (art. 6:230m BW).${ }^{24}$ Zo dient de verkoper de consument te informeren over zijn identiteit en adres, de belangrijkste kenmerken en de prijs van de zaak en het al dan niet bestaan van een herroepingsrecht, de termijn en de voorwaarden daarvan en de wijze waarop het herroepingsrecht kan worden uitgeoefend.

Dit laatste punt hangt samen met de tweede wijziging die het Nederlandse privaatrecht als gevolg van de richtlijn heeft ondergaan, te weten het recht van de consument om de overeenkomst binnen veertien dagen nadat hij de zaak heeft ontvangen zonder opgave van redenen te ontbinden (art. 6:230o $\mathrm{BW})$, zonder dat hem daartoe een vergoeding ${ }^{25}$ in rekening kan worden gebracht. ${ }^{26}$ De gedachte achter dit ontbindingsrecht is onder andere dat de consument bij een koop op afstand, anders dan bij een fysieke koop, de zaak niet kan zien of uitproberen. Om deze informatieachterstand ten opzichte van een fysieke koop tegen te gaan, mag de consument de koopovereenkomst binnen veertien dagen na ontvangst zonder opgave van reden 'ontbinden'. ${ }^{27}$ Het herroepingsrecht kan dan ook als sluitstuk worden gezien van de informatieplicht. Beide rechtsfiguren beogen de consument te beschermen tegen onvoldoende weloverwogen beslissingen.

\subsection{Positieve of negatieve mechanismen?}

De vraag is natuurlijk wel of deze nieuwe elementen in het Nederlandse privaatrecht zijn toe te juichen, of veeleer zijn te beschouwen als ongewilde Fremdkörper in het recht. Vanuit het perspectief van de consument bezien, is zijn positie in zijn algemeenheid inderdaad aanzienlijk verbeterd. Wij wijzen in dit verband op de evaluatie van de Richtlijn consumentenrechten door de Europese Commissie. ${ }^{28}$ Hieruit blijkt dat door de inwerkingtreding van de richtlijn de verschillen in wetgeving op het gebied van koop op afstand tussen de lidstaten grotendeels zijn verdwenen, wat met name in grensoverschrijdende situaties heeft bijgedragen aan meer rechtszekerheid voor verkopers en consumenten. Bovendien is uit de vergelijkende analyse van de wetgeving tussen de lidstaten voor en na de omzetting van de richtlijn gebleken dat de consument in

24. Voor de diverse sanctionering daarvan: M.O. Thijsen, Precontractuele informatieplichten bij de online consumentenovereenkomst. Een evaluatie van de sanctionering van artikel 6:227b lid 1 en artikel $6: 230 \mathrm{~m}$ lid 1 BW, TvHC 2019/2.

25. De verzendkosten van het retourneren van de zaak behoeven echter niet aan de consument te worden vergoed (art. 6:230s lid 2 BW) en ook kan soms een vergoeding voor de eventueel opgetreden waardevermindering in rekening worden gebracht (art. 6:230s lid 3 BW).

26. Nader M.Y. Schaub, Het herroepingsrecht bij de overeenkomst op afstand, NTBR 2014/23.

27. Zie Kamerstukken II 2012/13, 33520, 3, p. 36. Overigens gaat het niet om een ontbindingsrecht in de zin van art. 6:265 BW, dat in werking treedt bij een tekortkoming en waarvoor de verzuimregeling geldt. Het betreft hier een ander soort beëindiging van het contract. Asser/Hijma 7-1 2019/160 noemt de term ontbinding minder gelukkig en betoogt dat 'vernietiging' beter was geweest.

28. Verslag van de Commissie aan het Europees Parlement en de Raad over de toepassing van Richtlijn 2011/83/EU, COM(2017)259 def. 


\section{Maandblad \\ Vermogensrecht}

de meeste, zo niet alle lidstaten beter wordt beschermd. ${ }^{29}$ Dat is zonder meer een gunstige ontwikkeling voor de consument. Maar wij plaatsen ook kanttekeningen bij de twee hiervoor behandelde nieuwe rechtsfiguren in het Nederlandse privaatrecht.

Natuurlijk, door het herroepingsrecht is de positie van de consument aanzienlijk versterkt, juist vanwege het eenvoudige karakter van de uitoefening daarvan. Waar het Nederlandse privaatrecht strenge inhoudelijke eisen verbindt aan andere mogelijkheden om onder een reeds gesloten overeenkomst uit te komen (bijvoorbeeld vernietiging wegens wilsgebreken ex art. 3:44 $\mathrm{BW}$ en art. 6:228 $\mathrm{BW}$, wijziging op grond van onvoorziene omstandigheden ex art 6:258 BW en ontbinding ex art. 6:265 BW), kent het herroepingsrecht van de consument bij op afstand gesloten overeenkomsten geen enkele inhoudelijke voorwaarde. ${ }^{30}$ Van de consument wordt slechts gevraagd dat hij met een 'ondubbelzinnige verklaring' gebruik maakt van zijn herroepingsrecht (art. 6:230o lid 3 BW). Maar die eenvoud heeft ook een keerzijde: de bescherming van de consument is wat ons betreft op sommige punten doorgeschoten. Consumenten kunnen vanwege het hiervoor beschreven eenvoudige karakter van het herroepingsrecht misbruik maken van hun bevoegdheden, door bijvoorbeeld een product (eenmalig) te gebruiken en weer terug te sturen. ${ }^{31}$ Dit wordt ook wel het fenomeen van wardrobing genoemd, waarbij wordt gedoeld op de situatie dat bijvoorbeeld een cocktailjurk online wordt aangeschaft, om die eenmalig op een feest te dragen, en na de bewezen diensten op grond van de bedenktijd weer terug te sturen. Daarnaast mag de consument in het kader van het herroepingsrecht meer met een zaak doen dan wat gebruikelijk is in een gewone winkel en wij betwijfelen of dat gerechtvaardigd is. ${ }^{32}$ De consument bij een op afstand gesloten koopovereenkomst kan de zaak immers gedurende veertien kalenderdagen uitproberen, om de zaak vervolgens zonder opgave van reden en in principe zonder dat hij daar-

29. Verslag van de Commissie aan het Europees Parlement en de Raad over de toepassing van Richtlijn 2011/83/EU, COM(2017)259 def, p. 6.

30. Zie nader J. Hijma, Bedenktijd in het contractenrecht, in: Wettelijke bedenktijd. Preadviezen voor de Vereniging voor Burgerlijk Recht, Deventer: Kluwer 2004, p. 18 en W.L. Valk, Wanneer is een bedenktijdregeling gerechtvaardigd?, in: Wettelijke bedenktijd. Preadviezen voor de Vereniging voor Burgerlijk Recht, Deventer: Kluwer 2004, p. 91.

31. In gelijke zin J. Hijma, Bedenktijd in het contractenrecht, in: Wettelijke bedenktijd. Preadviezen voor de Vereniging voor Burgerlijk Recht, Deventer: Kluwer 2004, p. 22 en W.L. Valk, Wanneer is een bedenktijdregeling gerechtvaardigd?, in: Wettelijke bedenktijd. Preadviezen voor de Vereniging voor Burgerlijk Recht, Deventer: Kluwer 2004, p. 92.

32. Aldus M.B.M. Loos, De gebruiksvergoeding bij de ontbonden koop op afstand: het onderscheid tussen 'gebruiken' en 'uitproberen, $\mathrm{NtEr} 2010$, afl. 1, p. 27-31. voor een (gebruiks)vergoeding verschuldigd is, ${ }^{33}$ weer terug te sturen naar de verkoper (art. 6:230r BW). Bij een 'fysieke' koop kan dat niet, tenzij de verkoper vrijwillig de mogelijkheid geeft om de gekochte zaak te ruilen. Maar daartoe is de verkoper niet verplicht, terwijl hij aan deze ruilmogelijkheid bovendien nog aanvullende eisen kan stellen.

Gebruikmaking van het herroepingsrecht is in principe kosteloos, maar wel kan een vergoeding voor een mogelijke waardevermindering of beschadiging van de zaak bij de consument in rekening worden gebracht als 'een behandeling van de zaak verder is gegaan dan noodzakelijk om de aard, de kenmerken en de werking daarvan vast te stellen' (art. 6:230s lid 3 BW). Zo mag de consument de gekochte zaak uitpakken en uitproberen: een kledingstuk mag worden gepast, een computer mag worden aangezet ${ }^{34}$ en het plastic mag van een matras worden gehaald. ${ }^{35}$ Maar als de consument meer heeft gedaan dan nodig was om de werking van de zaak vast te stellen, zoals wanneer hij een kledingstuk een paar keer heeft gedragen of de stofzuiger die een paar keer is gebruikt, ${ }^{36}$ dan is hij schadeplichtig voor de waardevermindering van de zaak. Dit zou weliswaar een rem kunnen vormen op misbruik van het herroepingsrecht, maar dat blijkt slechts in beperkte mate het geval te zijn. De bewijslast rust namelijk bij de verkoper en in de praktijk is het moeilijk om de grens tussen een 'normaal' en een verdergaand gebruik vast te stellen. ${ }^{37}$ Daarnaast ondervinden verkopers geregeld problemen bij het beoordelen van de (hoogte van de) waardevermindering van de teruggestuurde zaken en het opnieuw verkopen ervan. Kortom, het herroepingsrecht leidt tot kosten bij de verkopers. ${ }^{38}$ Wellicht kan dat verlies uiteindelijk (gedeeltelijk) worden doorberekend in de koopprijs, maar dat betekent wel dat consumenten die niet of nauwelijks gebruikmaken van het herroepingsrecht indirect de

33. Dat geen gebruiksvergoeding, oftewel een vergoeding zuiver voor het kunnen gebruiken van de zaak gedurende de bedenktijd, in rekening kan worden gebracht volgt uit HvJ EG 3 september 2009, C-489/07, ECLI:EU:C:2009:502 (Messner). Daar ging het om een notebook die na enige tijd gebruikt te zijn werd teruggestuurd. De verkoper bracht een gebruiksvergoeding in rekening, ter hoogte van de huur van een notebook over de periode dat de consument van de notebook gebruik had kunnen maken. Volgens het Hof is een gebruiksvergoeding in algemene zin niet toelaatbaar, behalve in de uitzonderlijke situatie dat de zaak is gebruikt 'op een wijze die onverenigbaar is met de beginselen van burgerlijk recht, zoals dat van de goede trouw of van ongerechtvaardigde verrijking'.

34. Kamerstukken II 2012/13, 33520, 3, p. 46.

35. In HvJ EU 27 maart 2019, C-681/17, ECLI:EU:C:2019:255 (Ledowski) bevestigt het Hof dat het enkele gebruik van een matras niet betekent dat niet meer van het herroepingsrecht gebruik kan worden gemaakt, zolang hierdoor het product niet definitief ongeschikt is voor een nieuw gebruik door een derde of voor een nieuwe verkoop.

36. Zie voor meer voorbeelden die de dagelijkse praktijk blijken te zijn bij bol.com: www.volkskrant.nl/nieuws-achtergrond/het-volkskrantgeluidvijf-weken-undercover-bij-een-distributiecentrum-van-bolcom $\sim$ b41f958d/.

37. Vergelijk o.m. C.M.D.S. Pavillon, De richtlijn consumentenrechten, in: E.H. Hondius en G.J. Rijken (red.), Handboek Consumentenrecht, Zutphen: Uitgeverij Paris 2015, p. 59, die spreekt van een grijs gebied tussen 'even testen' en 'gebruiken'.

38. Verslag van de Commissie aan het Europees Parlement en de Raad over de toepassing van Richtlijn 2011/83/EU, COM(2017)259 def, p. 7. 
dupe worden van consumenten die hier wel (veelvuldig) gebruik van maken.

Ook met betrekking tot de (hoeveelheid aan) informatieverplichtingen van de verkoper, vragen wij ons af of de richtlijn (en daarmee de Nederlandse regeling van art. 6:230m BW) haar doel niet voorbijschiet. Om te beginnen lezen consumenten de verstrekte informatie vaak niet, zodat de informatieverstrekking vaak nodeloos is. ${ }^{39}$ Verder leidt de hoeveelheid aan informatie die moet worden verstrekt vaak tot een information overload: het fenomeen waarbij consumenten vaak moeite hebben met het nemen van een goede beslissing als ze worden geconfronteerd met grote hoeveelheden informatie. ${ }^{40}$ Dat houdt verband met het gegeven dat consumenten, bij een teveel aan informatie, op zoek gaan naar een eenvoudige manier om een beslissing te kunnen nemen als gevolg waarvan niet alle (essentiële) informatie bij de beslissing wordt meegewogen. ${ }^{41}$ Consumenten hebben uiteraard informatie nodig om een goed besluit te kunnen nemen, maar te veel informatie kan dus averechts werken. In dat opzicht leidt de door Europa geïnitieerde informatieverplichting niet altijd tot een wezenlijke verbetering van de positie van de consument, terwijl het de verkoper met een flinke verplichting belast.

\section{Non-conformiteit en remedies}

\subsection{Non-conformiteit}

Zoals hiervoor al kort opgemerkt, is ter versterking van de rechtspositie van de consument en het vertrouwen van de consument in de interne markt, in 1999 de Richtlijn consumentenkoop ${ }^{42}$ aangenomen. ${ }^{43}$ De richtlijn beoogt een gemeenschappelijke minimale beschermingsregeling te scheppen met betrekking tot de rechten van de consument bij nietnakoming van de (grensoverschrijdende) overeenkomst door de verkoper. Aangezien de richtlijn diep ingreep op het nationale recht van de lidstaten, werd deze richtlijn als misschien

39. O. Ben-Shahr, The Myth of the Opportunity to Read in Contract Law, ERCL 2009/1, p. 1. e.v. Ten aanzien van online-contracten: Y. Bakos, F. Marotta-Wurgler \& D.R. Trossen, Does Anyone Read the Fine Print? Consumer Attention to Standard-Form Contracts, The Journal of Legal Studies $2014 / 1$, p. 1-35. Ten aanzien van algemene voorwaarden ter zake van privacy: G.R. Milne \& M.J. Culnan, Strategies for reducing online privacy risks: why consumers read (or don't read) online privacy notes, Journal of Interactive Marketing 2004/18, p. 15-29.

40. B.B. Duivenvoorde, De gemiddelde consument als standaard bij misleiding - Een kritische blik vanuit de gedragswetenschappen, in: W.H. van Boom, I. Giesen en A.J. Verheij (red.), Capita Civilologie. Handboek empirie en privaatrecht, Den Haag: Boom Juridische uitgevers 2013, p. 151.

41. A.L.M. Keirse \& A. van Onna, Naar een effectieve bescherming van de koper van een woning, in: W.H. van Boom, I. Giesen en A.J. Verheij (red.), Capita Civilologie. Handboek empirie en privaatrecht, Den Haag: Boom Juridische uitgevers 2013, p. 656.

42. Richtlijn 1999/44/EG van 25 mei 1999 betreffende bepaalde aspecten van de verkoop van en de garanties voor consumptiegoederen, PbEG 1999, L 171/12.

43. Zie $\operatorname{COM}(95) 520$ def, p. 1-4 en de overwegingen 2-5 van de preambule bij de Richtlijn consumentenkoop. wel de meest vergaande richtlijn van die periode gezien. ${ }^{44}$ Hoewel in Nederland, sinds de invoering van het huidige Burgerlijk Wetboek in 1992, in Titel 7.1 BW reeds een regeling inzake consumentenkoop bestond, moest deze titel ter implementatie van de richtlijn per 1 mei 2003 op een aantal punten flink worden aangepast.

Een van de nieuwe punten die door deze richtlijn in het BW is terechtgekomen en destijds veel aandacht heeft gekregen, is een aanvulling op de bestaande non-conformiteitsregeling van art. 7:17 BW. ${ }^{45}$ Daaraan is voor de consumentenkoop art. 7:18 lid 2 BW toegevoegd, op grond waarvan wordt vermoed dat de zaak bij aflevering niet aan de overeenkomst heeft beantwoord indien de afwijking van het overeengekomene zich binnen een termijn van zes maanden ${ }^{46}$ na aflevering openbaart. ${ }^{47}$ De consument behoeft gedurende deze eerste zes maanden na aankoop dus niet te bewijzen dat het gebrek al bij aflevering bestond, hetgeen noodzakelijk is om zich op nonconformiteit te beroepen. Het gaat hier om een weerlegbaar bewijsvermoeden, dat niet geldt indien de aard van de zaak of van de afwijking zich daartegen verzet.

Bij de introductie van de Richtlijn consumentenkoop, werd met name dit aspect als een grote wijziging van het Nederlandse recht beschouwd, die tot veel commotie heeft geleid. Frenk omschrijft de onrust over deze zesmaandentermijn als volgt:

'De indruk bestond dat de verkoper gedurende deze termijn diende in te staan voor elk gebrek. In kringen van de detailhandel - alsook in de media - werd al gesproken over een wettelijk verplichte garantietermijn. Dit alles is niet juist. Artikel 18 lid 2 bevat niet meer dan een regel van bewijsrecht. ${ }^{48}$

Dat is een juiste observatie, maar deze regel van bewijsrecht versterkt wel in aanzienlijke mate de positie van de consument. Voor een verkoper zal het immers vaak moeilijk zijn om dit bewijsvermoeden te ontkrachten, met als gevolg dat gere-

44. Aldus o.m. J.M. Smits, Naar een nieuw Europees consumentenkooprecht, NJB 2000, p. 1825.

45. De zaak moet dus bij aflevering aan de overeenkomst beantwoorden (lid 1), hetgeen erop neerkomt dat de zaak de eigenschappen moet bezitten die de koper op grond van de overeenkomst mocht verwachten.

46. Dat wordt in de toekomst een jaar: zie art. 11 Richtlijn 2019/771/EU betreffende bepaalde aspecten van overeenkomsten voor de verkoop van goederen, tot wijziging van Verordening (EU) 2017/2394 en Richtlijn 2009/22/EG, en tot intrekking van Richtlijn 1999/44/EG, PbEU 2019, L 136/28.

47. Tenzij de aard zich daartegen verzet, hetgeen bijv. het geval kan zijn bij huisdieren of bij levensmiddelen: zie nader Asser/Hijma 7-I 2019/480-481.

48. N. Frenk, Herziening van de regeling consumentenkoop, AA 2003/12, p. 957. 


\section{Maandblad \\ Vermogensrecht}

geld zal worden aangenomen dat een zaak non-conform is. ${ }^{49}$ Een belangrijke wijziging van het Nederlandse recht dus, die de positie van de consument versterkt.

\subsection{Nieuwe remedies?}

De Richtlijn consumentenkoop heeft verder geleid tot de komst van een 'nieuwe' remedie bij een non-conforme koop: de in art. 7:22 lid 1 BW neergelegde regel dat de koper bij een consumentenkoop het recht heeft om in geval van non-conformiteit 'de prijs te verminderen in evenredigheid met de mate van afwijking van het overeengekomen'. Dit veelbesproken ${ }^{50}$ recht op prijsvermindering, ook wel de actio quanti minoris, is echter geen (wezenlijk) nieuwe remedie: het is een vorm van partiële ontbinding van de overeenkomst, namelijk voor het deel van de non-conforme koop, dat leidt tot een evenredige koopprijsvermindering. Prijsvermindering kan dus ook met de klassieke ontbindingsregeling uit art. 6:265 BW worden bereikt en is dus geen nieuw element in het Nederlandse recht. Toch werd implementatie van de actio quanti minoris nodig geacht, omdat een expliciete implementatie van dit recht zou bijdragen aan de kenbaarheid voor de consument van het recht op prijsvermindering. ${ }^{51}$ Maar een regel die tot een wezenlijke verandering in het Nederlandse recht heeft geleid, is het dus zeker niet.

\subsection{De échte gamechanger: het getrapte stelsel van remedies}

Een van de kernonderwerpen van de Richtlijn consumentenkoop betreft het zogenoemde getrapte stelsel van remedies in geval van non-conformiteit. ${ }^{52}$ Dit stelsel houdt in dat de consument in eerste instantie het kosteloze herstel of de kosteloze vervanging van de zaak moet vorderen, tenzij dat onmogelijk of buiten verhouding zou zijn. ${ }^{53}$ Pas wanneer de consument geen aanspraak kan maken op deze vormen van nakoming (herstel of vervanging), of indien de verkoper niet binnen een redelijk termijn, of niet zonder ernstige overlast voor de consument, tot herstel of vervanging is overgegaan, heeft de consument recht op prijsvermindering of ontbinding van de

49. Uit HvJ EU 4 juni 2015, C-497/13, ECLI:EU:C:2015:357, NJ 2016/148 (Faber/Autobedrijf Hazet Ochten BV) lijkt ook te volgen dat het niet gaat om het ontzenuwen van het vermoeden, dus om het zaaien van twijfel, maar om het leveren van tegenbewijs: zie ook Asser/Hijma 7-I 2019/479

50. Zie o.m. Asser/Hijma 7-I 2019/663 en 715-716; M.B.M. Loos, Consumentenkoop (Mon. BW nr. B65b), Deventer: Kluwer 2019, nr. 36.

51. Ibid.

52. Zie voor een uitvoerige bespreking van de wijzigingen die de implementatie van de richtlijn consumentenkoop met zich bracht J.M. Smits, De richtlijn consumentenkoop en het Nederlandse recht, in: Loos e.a. (red.), De richtlijn consumentenkoop in perspectief, Den Haag 2003, p. 1-27.

53. Zie art. 3 lid 3 Richtlijn consumentenkoop.

54. Zie art. 3 lid 5 Richtlijn consumentenkoop. Mogelijk kan Richtlijn 2019/771/EU betreffende bepaalde aspecten van overeenkomsten voor de verkoop van goederen, tot wijziging van Verordening (EU) 2017/2394 en Richtlijn 2009/22/EG, en tot intrekking van Richtlijn 1999/44/EG, PbEU 2019, L 136/28 verandering brengen in dit getrapte stelsel, zie hierover M.B.M. Loos, Herziening regelingen kooprecht en digitale inhoud aanstaande, TvC 2019/3. koopovereenkomst. ${ }^{54}$ Het primaat bij de consumentenkoop ligt dus bij de nakomingsvordering.

Aangezien de Nederlandse wet geen getrapt stelsel van remedies kende, noopte de Richtlijn consumentenkoop tot een aantal aanpassingen. Zo kende de Nederlandse wet aan de (consument)koper, in geval van non-conformiteit, het recht tot herstel of vervanging wel al toe (zie art. 7:21 lid 1 BW), maar werd aan de verkoper, indien de (consument)koper het recht op herstel of vervanging wilde uitoefenen, de bevoegdheid gegeven om daarvoor in de plaats voor vervanging of teruggave van de koopprijs te kiezen. Aangezien de richtlijn de keuze tussen herstel of vervanging aan de consument toedeelt, is deze bepaling met de implementatie van de richtlijn derhalve komen te vervallen. ${ }^{55}$ Bovendien is in de Nederlandse wet, conform de Richtlijn consumentenkoop, specifiek voor de consument de bepaling opgenomen dat aan hem alleen dan geen recht op herstel of vervanging toekomt, indien herstel of vervanging onmogelijk is of niet van de verkoper kan worden gevergd (zie art. 7:21 lid $4 \mathrm{BW}$ ). Het recht op herstel of vervanging is daardoor sterker geworden dan bij een nietconsumentenkoop. ${ }^{56}$ Immers, bij consumentenkoop kunnen deze vormen van nakoming slechts worden geweigerd als dat onmogelijk of niet proportioneel zou zijn, terwijl de toetssteen bij een normale koop de 'redelijkheid' is. Anderzijds is dit recht op herstel of vervanging, wat gewoon vormen van nakoming zijn, minder sterk dan bij andersoortige overeenkomsten: daar heeft een schuldeiser immers als uitgangspunt altijd een recht om nakoming te vorderen (art. 3:296 BW). ${ }^{57}$

Daarnaast is in de Nederlandse wet uitdrukkelijk opgenomen dat het recht van de consument op twee andere remedies - prijsvermindering en ontbinding - pas ontstaat wanneer herstel en vervanging onmogelijk zijn of niet van de verkoper gevergd kunnen worden, dan wel de verkoper niet binnen een redelijke termijn en zonder ernstige overlast voor de consument tot herstel of vervanging is overgegaan (zie art. 7:22 lid 2 $\mathrm{BW}$ ). Aangezien de eis van de schriftelijke ingebrekestelling als vereiste voor prijsvermindering of ontbinding niet in lijn werd gezien met de Richtlijn consumentenkoop, is het verzuimvereiste niet in deze bepaling (van art. 7:22 lid $2 \mathrm{BW}$ ) opgenomen. ${ }^{58}$ Dit is in afwijking van de regeling inzake ontbinding bij een niet-consumentenkoop, waar wel expliciet een verzuimvereiste wordt gesteld (zie art. 6:265 lid 2 BW).

55. Kamerstukken II, 2000/01, 27809, 3, p. 6-7. Deze bepaling was opgenomen in art. 7:21 lid 2 oud BW.

56. Aldus M.B.M. Loos, Consumentenkoop en garanties volgens het herziene consumentenkooprecht, NTER 2003, afl. 6, p. 157.

57. Alleen in bijzondere omstandigheden kan een recht op nakoming worden geweigerd: zie HR 5 januari 2001, ECLI:NL:HR: 2001:AA9311, NJ 2001/79 (Multi Vastgoed/Nethou) op grond waarvan eiser niet geheel vrij is in zijn keuze tussen het recht op nakoming en schadevergoeding '(...) maar daarbij gebonden [is] aan de eisen van redelijkheid en billijkheid, waarbij mede de gerechtvaardigde belangen van de wederpartij een rol spelen'.

58. Zie Kamerstukken II 2001/02, 27809, 8, p. 3. 


\subsection{Heeft het getrapte stelsel tot een verbetering geleid?}

Vanuit het perspectief van de consument, is het in de vorige paragraaf uiteengezette getrapte stelsel van remedies niet over de hele linie een verbetering in het Nederlandse recht gebleken. Wat betreft het primaat van de nakomingsvordering lijkt op het eerste gezicht een ongunstiger rechtspositie voor de consument te zijn gecreëerd dan de koper bij een niet-consumentenkoop. Daar is de koper in beginsel namelijk volledig vrij om te kiezen tussen bijvoorbeeld het recht op nakoming of ontbinding, terwijl de consumentenkoop die vrije keuze niet heeft: hij moet in beginsel eerst nakoming vragen, voordat de andere remedies in zicht komen. In de praktijk is dit ontstane verschil evenwel kleiner dan dit in eerste instantie lijkt. ${ }^{59}$ Ook de koper bij een niet-consumentenkoop die in geval van nonconformiteit de koopovereenkomst wil ontbinden, zal in verband met de werking van het verzuimvereiste immers in de regel de verkoper eerst een redelijke termijn moeten gunnen om alsnog correct na te komen (zie art. 6:82 lid 1 jo. art. 6:265 lid $2 \mathrm{BW}$ ). In die zin is ook voor de niet-consumentenkoop nodig dat eerst nakoming wordt gevraagd, tenzij nakoming blijvend of tijdelijk onmogelijk is in welk geval de verzuimregeling in zijn geheel niet geldt, of indien verzuim 'rauwelijks' zonder ingebrekestelling intreedt (art. 6:83 BW).

In sommige gevallen komt de consument desondanks een beperkter recht op ontbinding toe dan de koper bij een nietconsumentenkoop. Wanneer bijvoorbeeld reeds bij de aflevering van de zaak de zaak non-conform blijkt te zijn en duidelijk is dat de verkoper niet bereid is te herstellen, kan de koper bij een niet-consumentenkoop direct overgaan tot ontbinding, nu het verzuim van de verkoper intreedt zonder dat hem een redelijk termijn hoeft te worden gegund om alsnog correct na te komen (zie art. 6:83 sub c BW). De consument kan in een dergelijk geval echter niet direct overgaan tot ontbinding, omdat hij de verkoper eerst een verzoek tot herstel of vervanging zal moeten doen. Pas wanneer de verkoper niet, dan wel niet binnen een redelijke termijn en zonder ernstige overlast voor de consument tot herstel of vervanging is overgaan, kan de consument de koopovereenkomst ontbinden. ${ }^{60}$ Een soortgelijk geval doet zich voor wanneer een fatale termijn is overeengekomen waarbinnen de verkoper zijn verplichtingen dient na te komen, de verkoper reeds voor het verstrijken van deze fatale termijn de zaak aflevert, de zaak non-conform blijkt te zijn, maar herstel zodanig lang duurt dat dit niet voor afloop van de fatale termijn kan zijn gerealiseerd. Het klassieke voorbeeld van de bruidsjurk doemt op: wanneer vóór de afgesproken tijdstip van aflevering, maar vlak voor het huwelijk blijkt dat de bruidsjurk niet aan de overeenkomst beantwoordt en herstel te lang zal duren, kan de bruid de koopovereenkomst in beginsel pas na afloop van het huwelijk ontbinden, aangezien herstel en vervanging pas dan onmogelijk zijn

59. Zie hierover o.m. Asser/Hijma 7-I 2019/671 en M.B.M. Loos, Consumentenkoop (Mon. BW nr. B65b), Deventer: Kluwer 2019, nr. 36.

60. In gelijke zin F.P.C. Strijbos, Ontbinding van een consumentenkoop na levering van een gebrekkige zaak, NTBR 2016/36, afl. 16. geworden. ${ }^{61}$ De koper bij een niet-consumentenkoop kan in een dergelijk geval echter wél direct tot ontbinding overgaan (zie art. 6:80 jo. 6:83 sub a BW)..$^{62}$

\section{De klachtplicht}

\subsection{De Richtlijn consumentenkoop en de klachtplicht}

Een laatste te bespreken ontwikkeling in het Nederlandse privaatrecht met betrekking tot de consumentenkoop betreft een ander onderwerp van de Richtlijn consumentenkoop, te weten de klachtplicht. De klachtplicht beoogt de verkoper te beschermen tegen late en daardoor moeilijk betwistbare klachten. Ook op dit gebied heeft de richtlijn genoopt tot een wijziging in Titel 7.1 BW en daarmee tot een verandering in de rechtspositie van de Nederlandse consument.

In de Nederlandse wet is al sinds 1992 een klachtplicht van Nederlandse makelij opgenomen. Op grond van art. 7:23 lid 1 BW verliest de koper in geval van non-conformiteit al zijn rechten, waaronder die hiervoor in paragraaf 4.3 zijn beschreven, indien hij de verkoper niet binnen bekwame tijd nadat hij dit heeft ontdekt of redelijkerwijs had behoren te ontdekken daarvan kennis heeft gegeven (zie art. 7:23 lid 1 eerste volzin BW) ${ }^{63}$ De klachtplicht houdt niet alleen in dat de koper binnen een redelijk termijn bij de verkoper moet klagen, maar ook dat op hem de plicht rust om de afgeleverde zaak binnen een redelijke termijn op haar conformiteit te onderzoeken: dat laatste volgt uit de zinsnede dat de koper de non-conformiteit 'redelijkerwijs had behoren te ontdekken'.

Als gevolg van de Richtlijn consumentenkoop ${ }^{64}$ is in de Nederlandse wet voor de consument een afwijkende regeling inzake de klachtplicht opgenomen. Zo is de gunstiger bepaling opgenomen dat de termijn waarbinnen de consument bij de verkoper moet klagen pas gaat lopen vanaf het moment van ontdekking van de non-conformiteit, en dus niet vanaf het moment waarop de consument de non-conformiteit had behoren te ontdekken (zie art. 7:23 lid 1 derde zin BW). Anders dan de 'normale' klachtplicht uit art. 7:23 lid $1 \mathrm{BW}$ rust op de consument dus geen onderzoeksplicht. Daarnaast is voor de consument specifiek bepaald dat de feitelijke klachttermijn in ieder geval niet eerder kan verlopen dan twee maanden na ontdekking van het gebrek (zie ook art. 7:23 lid 1 derde zin BW). Overigens kan deze termijn langer duren in geval van bijzondere omstandigheden, bijvoorbeeld indien sprake is

61. Een soortgelijk geval doet zich voor in Rb. Alkmaar 20 juni 2011, ECLI:NL:RBALK:2011:BR1997. De kantonrechter oordeelt dat herstel van de bruidsjurk na de huwelijksdag niet opportuun is. Hieruit volgt in ieder geval niet dat reeds vóór de afloop van de fatale termijn kan worden ontbonden indien herstel of vervanging in praktische zin nog mogelijk is. Zie hierover ook F.P.C. Strijbos, Ontbinding van een consumentenkoop na levering van een gebrekkige zaak, NTBR 2016/36, afl. 16 .

62. In gelijke zin F.P.C. Strijbos, Ontbinding van een consumentenkoop na levering van een gebrekkige zaak, NTBR 2016/36, afl. 16.

63. Een vergelijkbare klachtplicht voor andere overeenkomsten is in art. 6:89 BW opgenomen.

64. Meer specifiek: als gevolg van art. 5 lid 2 Richtlijn consumentenkoop. 


\section{Maandblad \\ Vermogensrecht}

van een grensoverschrijdende koopovereenkomst, of indien de aard van de zaak dit rechtvaardigt. ${ }^{65}$ Deze 'Europese' klachtplicht voor consumenten heeft wat ons betreft niet tot een aardverschuiving in het Nederlandse recht geleid, juist omdat de klachtplicht al een bekend fenomeen was. Wel heeft het Unierecht genoopt tot een bijstelling van deze regeling.

\subsection{Gunstige ontwikkeling voor de consument?}

Hoewel de rechtspositie van de Nederlandse consument met deze twee wijzigingen ten aanzien van de klachtplicht is verbeterd ten opzichte van die van de koper bij een niet-consumentenkoop, is het duidelijk dat de klachtplicht in algemene zin nadelig is voor de consument. De consument zal zich immers veelal minder bewust zijn van zijn rechtspositie dan de koper bij een niet-consumentenkoop. ${ }^{66}$ Bovendien is de sanctie, verval van alle rechten (naast het recht op nakoming, ontbinding of schadevergoeding ook bijvoorbeeld het recht op een beroep op dwaling, bedrog en onrechtmatige daad) hard. Opvallend is dat de Richtlijn consumentenkoop niet verplichtte tot de implementatie van de klachttermijn. ${ }^{67}$ Aangezien de richtlijn uitging van minimumharmonisatie, had de Nederlandse wetgever er dus voor kunnen kiezen om de consument vrij te stellen van de klachtplicht. Een andere mogelijkheid voor de Nederlandse wetgever was om ook bij de gevolgen van schending van de klachtplicht, verval van alle rechten, rekening te houden met de consument en bijvoorbeeld niet alle rechten (geheel) te laten vervallen bij het verzaken van de klachtplicht. Mede gelet op de doelstellingen van de Richtlijn consumentenkoop, de verbetering van de rechtspositie van de consument en het stimuleren van de consument tot het doen van grensoverschrijdende aankopen, kan derhalve afgevraagd worden of het in stand houden van de klachtplicht voor de consument, dan wel de sanctie van verval van alle rechten bij schending van de klachtplicht door de consument, wel gerechtvaardigd is, of dat wat dit aspect betreft de positie van de verkoper te sterk is. ${ }^{68}$

\section{Toekomstige gamechangers?}

Kortom, in het consumentenkooprecht zijn enkele belangrijke gamechangers tot stand gebracht, die ook het Nederlandse privaatrecht hebben gewijzigd. De EU was aanvankelijk echter nog ambitieuzer en had zelfs het plan opgevat om een volledig geharmoniseerd Europees kooprecht te bewerkstelligen: het Gemeenschappelijk Europees Kooprecht ('GEKR'). Dat GEKR bleek te vergaand en is uiteindelijk ingetrokken. Wat dat betreft zijn de ontwikkelingen tot een voorlopige standstill gekomen. Wat thans rest zijn richtlijnen die voor een deel uitgaan van minimumharmonisatie en slechts een enkeling van volledige harmonisatie. De vraag rijst of het consumenten-

65. Kamerstukken II 2000/01, 27809, 3, p. 3 en 10.

66. H.N. Schelhaas \& A.I. Schreuder, Weeffouten bij consumentenkoop, in: F. van de Pol e.a. (red.), Vijftig weeffouten in het BW, Nijmegen: Ars Aequi, 2017, p. 272.

67. Zie art. 5 lid 2 Richtlijn consumentenkoop.

68. In gelijke zin o.m. J.G.H. Meijerink, De klachtplicht in Europees perspectief, NTBR 2010, afl. 6 en S. Tamboer, De klachtplicht van de koper in het Nederlandse kooprecht, TvC 2008, p. 225. kooprecht uitontwikkeld is en tot stilstand is gekomen, zoals wel wordt gesteld. ${ }^{69}$

Dat is niet het geval. Wij zien een aantal toekomstige ontwikkelingen in Europa, die het Nederlandse recht zullen beïnvloeden en mogelijk tot nieuwe gamechangers zullen gaan leiden. Want het consumentenrecht is in ieder geval op Europees niveau nog steeds in beweging, zo blijkt onder meer uit de uitvaardiging van een 'New Deal' door de Europese Commissie in 2018. Deze 'New Deal' behelst een pakket maatregelen ter verdere versterking van de positie van de consument. ${ }^{70}$ Die beoogde maatregelen hebben onder meer betrekking op een doeltreffender handhaving van consumentenrechten, het verbeteren van communicatie jegens de consument en het verstevigen van het consumentenbeleid bij technologische vernieuwingen. ${ }^{71}$ Daarnaast wordt gewerkt aan effectiever manieren om de rechten van consumenten in het algemeen te handhaven, zoals de voorgestelde collectieve actie op EU-niveau. ${ }^{72}$ Het Nederlandse recht kent echter al een vorm van een collectieve actiemogelijkheid en dit is dus op zichzelf niet een novum voor het Nederlandse recht.

Verder wijzen wij op de recent in mei 2019 uitgevaardigde vernieuwde Richtlijn consumentenkoop, ${ }^{73}$ die de oude uit 1999 stammende Richtlijn consumentenkoop vervangt en tot wijzigingen zal leiden. Zo wordt onder meer voorzien in een regeling ten aanzien van de koop van (meegeleverde) software. Mede gezien het uitgangspunt van volledige harmonisatie van deze richtlijn ${ }^{74}$ zal dit tot wijzigingen in onder meer het conformiteitsvereiste van art. 7:17 BW leiden. ${ }^{75}$

In het verlengde van deze richtlijn denken wij dat de echte gamechangers van de toekomst liggen in consumentenbeschermende maatregelen ten aanzien van digitale ontwikkelingen, waar al de nodige Europese activiteit in is te bespeuren. Zo is op dezelfde dag dat de hiervoor aangehaalde nieuwe Richtlijn consumentenkoop het licht zag, de Richtlijn digitale inhoud

69. E.H. Hondius, De toekomst van het consumentenrecht, TvC 2011, p. 137.

70. Communication from the Commission to the European Parliament, the Council and the European Economic and Social Committee, A New Deal for Consumers, COM/2018/183. Een uitvloeisel hiervan is het plan om onder meer de richtlijn oneerlijke bedingen in handelstransacties en de richtlijn oneerlijke handelspraktijken te moderniseren: zie richtlijnvoorstel van 11 april 2018, $\operatorname{COM}(2018) 185$ def.

71. Communication from the Commission to the European Parliament, the Council and the European Economic and Social Committee, A New Deal for Consumers, $\operatorname{COM}(2018) 183$ def.

72. Zie bijv. richtlijn betreffende representatieve vorderingen ter bescherming van de collectieve belangen van consumenten en tot intrekking van Richtlijn 2009/22/EG, PbEU 2019, L 110/30.

73. Richtlijn (EU) 2019/771 betreffende bepaalde aspecten van overeenkomsten voor de verkoop van goederen, tot wijziging van Verordening (EU) 2017/2394 en Richtlijn 2009/22/EG, en tot intrekking van Richtlijn 1999/44/EG, PbEU 2019, L 136/28.

74. Art. 4 Richtlijn consumentenkoop.

75. Zo verplicht art. 6 van deze richtlijn dat goederen met alle toebehoren en instructies moeten worden geleverd en ook van updates moeten worden voorzien: een 'slim' product is dus non-conform als het niet gedurende een redelijke periode van een update wordt voorzien. 
in werking getreden. ${ }^{76}$ Het algemene doel is om een eenvormige Digital Single Market te creëren waarin binnen de EU digitale goederen en diensten vrij kunnen worden verhandeld. ${ }^{77}$ Zo wordt bijvoorbeeld beoogd om de consumentenbeschermende maatregelen uit te breiden naar overeenkomsten waarbij niet in geld maar met data voor diensten wordt betaald (art. 1 lid 1 Richtlijn digitale inhoud): de consument kan in een dergelijk geval schijnbaar 'gratis' gebruik maken van - bijvoorbeeld - een platform als Facebook of Instagram, maar moet hierbij wel zijn (privacy)rechten op data prijsgeven en betaalt dus in wezen met persoonsgegevens. ${ }^{78}$ Door dit soort overeenkomsten onder de consumentenbescherming te brengen, komen de consument meer rechten toe indien de diensten die hij geleverd krijgt van onvoldoende kwaliteit zijn. De Richtlijn digitale inhoud bepaalt bijvoorbeeld dat in geval van ontbinding van de overeenkomst wegens een tekortkoming, de handelaar verplicht is om af te zien van het gebruik van persoonsgegevens (art. 16 Richtlijn digitale inhoud). ${ }^{79}$ Ook voorziet deze richtlijn in een lange garantietermijn van liefst twee jaar bij de koop van digitale inhoud en/of diensten (art. 11 lid 2 Richtlijn digitale inhoud).

Wij denken dat het consumentenkooprecht ook in de toekomst blijvend zal worden beïnloed door Europese ontwikkelingen, die zich waarschijnlijk vooral ten aanzien van digitale ontwikkelingen zullen voordoen. De recent gepubliceerde richtlijn ten aanzien van digitale inhoud en diensten herbergt al enige kandidaten voor mogelijke gamechangers, zoals de gelijkschakeling van de koopovereenkomst die verplicht tot het betalen van een geldsom en de overeenkomst die verplicht tot het leveren van persoonsgegevens.

\section{Conclusies}

Het Nederlandse consumentenkooprecht wordt al enige decennia beïnvloed door het EU-recht. Deze Unierechtelijke invloed heeft tot verschillende ontwikkelingen in het Nederlandse recht geleid, de één ingrijpender dan de ander. Echte gamechangers voor de Nederlandse consument zijn wat ons betreft geweest de invoering van de regeling inzake op afstand gesloten overeenkomsten (afdeling 6.5.2B) en de invoering van het getrapte stelsel van remedies (art. 7:21 en $22 \mathrm{BW}$ ). Minder ingrijpende, maar desalniettemin belangrijke, ontwikkelingen die zijn teweeggebracht, betreffen onder andere de aanvulling van het bewijsvermoeden bij de non-conformi-

76. Richtlijn 2019/770/EU betreffende bepaalde aspecten van overeenkomsten voor de levering van digitale inhoud en digitale diensten, $\mathrm{PbEU}$ 2019, L 136/1. Zie voor een overzicht van de belangrijkste bepalingen van Richtlijn 2019/770 en Richtlijn 2019/771 en hoe deze zich verhouden tot de huidige regeling in Titel 7.1 BW: M.B.M. Loos, Herziening regelingen kooprecht en digitale inhoud aanstaande, TvC 2019/3.

77. Zie over de voorlopers van deze richtlijnen V. Mak, Op weg naar een Europese 'Digital Single Market', NJB 2016/397.

78. Zie C. Spierings, Het nieuwe goud: betalen met data', MvV 2019, afl. 6, p. s207-214.

79. Verder zijn gedetailleerdere regelingen opgenomen die bepalen wanneer sprake is van non-conformiteit van een digitale dienst of product (art. 7, 8 en 9 Richtlijn digitale inhoud), waaronder de situatie dat geen sprake is van adequate updates. teitsregeling (art. 7:18 lid $2 \mathrm{BW}$ ) en een wijziging van de klachtplicht (art. 7:23 lid 1 derde volzin BW).

De invloed van het Unierecht op het Nederlandse BW heeft in het algemeen geleid tot een betere juridische positie van de consument: met name het herroepingsrecht en het bewijsvermoeden. Wel hebben wij enige uitzonderingen belicht, zoals enkele elementen van het getrapte stelsel van remedies, terwijl ook de informatieplicht bij de koop op afstand averechts kan werken. Niet alle ontwikkelingen bestempelen wij als louter positief. Zo is het herroepingsrecht wat ons betreft niet in balans, is de introductie van het recht op prijsvermindering een nodeloze doublure en kan worden afgevraagd of de wetgever de klachtplicht voor de consument niet geheel had moeten laten vervallen. Wat ons betreft een potentiële gamechanger die door de wetgever is laten liggen.

$\mathrm{Al}$ met al is duidelijk dat het Unierecht het consumentenkooprecht ook in Nederland, dat al een regeling inzake de consumentenkoop kende, wezenlijk heeft beïnvloed en dat de komende tijd nog zal blijven doen. 